\title{
Publisher Correction: Orthogonal Cas9-Cas9 chimeras provide a versatile platform for genome editing
}

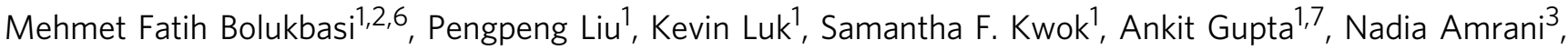 \\ Erik J. Sontheimer (10 ${ }^{3,4}$, Lihua Julie Zhu (1) ${ }^{1,4,5} \&$ Scot A. Wolfe ${ }^{1,2}$
}

Correction to: Nature Communications; https://doi.org/10.1038/s41467-018-07310-x; published online 19 November 2018

The original version of this Article contained errors in the author affiliations. Mehmet Fatih Bolukbasi was incorrectly associated with Bluebird Bio., Cambridge, MA, USA and Ankit Gupta was incorrectly associated with Exonics Therapeutics, Watertown, MA, USA. This has now been corrected in the HTML version of the Article. The PDF version of the Article was correct at the time of publication.

Published online: 10 December 2018

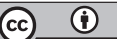

Open Access This article is licensed under a Creative Commons Attribution 4.0 International License, which permits use, sharing, adaptation, distribution and reproduction in any medium or format, as long as you give appropriate credit to the original author(s) and the source, provide a link to the Creative Commons license, and indicate if changes were made. The images or other third party material in this article are included in the article's Creative Commons license, unless indicated otherwise in a credit line to the material. If material is not included in the article's Creative Commons license and your intended use is not permitted by statutory regulation or exceeds the permitted use, you will need to obtain permission directly from the copyright holder. To view a copy of this license, visit http://creativecommons.org/licenses/by/4.0/.

(c) The Author(s) 2018

\footnotetext{
${ }^{1}$ Department of Molecular, Cell and Cancer Biology, University of Massachusetts Medical School, Worcester, MA, USA. ${ }^{2}$ Department of Biochemistry and Molecular Pharmacology, University of Massachusetts Medical School, Worcester, MA, USA. ${ }^{3}$ RNA Therapeutics Institute, University of Massachusetts Medical School, Worcester, MA, USA. ${ }^{4}$ Program in Molecular Medicine, University of Massachusetts Medical School, Worcester, MA, USA. ${ }^{5}$ Program in Bioinformatics and Integrative Biology, University of Massachusetts Medical School, Worcester, MA, USA. ${ }^{6}$ Present address: Exonics Therapeutics,

Watertown, MA, USA. ${ }^{7}$ Present address: Bluebird Bio., Cambridge, MA, USA. These authors contributed equally: Mehmet Fatih Bolukbasi, Pengpeng Liu Correspondence and requests for materials should be addressed to S.A.W. (email: scot.wolfe@umassmed.edu)
} 